Cornell Law Library

Scholarship@Cornell Law: A Digital Repository

Cornell Law Faculty Publications

Faculty Scholarship

$1-1-1996$

\title{
The Need for the Harmonisation of Trade Laws in the Southern African Development Community (SADC)
}

Muna Ndulo

Cornell LawSchool, mbn5@cornell.edu

Follow this and additional works at: http://scholarship.law.cornell.edu/facpub

Part of the International Law Commons, International Trade Commons, and the Law and Economics Commons

\section{Recommended Citation}

Ndulo, Muna, "The Need for the Harmonisation of Trade Laws in the Southern African Development Community (SADC)" (1996). Cornell Law Faculty Publications. Paper 60.

http://scholarship.law.cornell.edu/facpub/60

This Article is brought to you for free and open access by the Faculty Scholarship at Scholarship@Cornell Law: A Digital Repository. It has been accepted for inclusion in Cornell Law Faculty Publications by an authorized administrator of Scholarship@Cornell Law: A Digital Repository. For more information, please contact jmp8@cornell.edu. 


\section{THE NEED FOR THE HARMONISATION OF TRADE LAWS IN THE SOUTHERN AFRICAN DEVELOPMENT COMMUNITY (SADC)}

\section{Muna Ndulo*}

\section{A. INTRODUCTION}

The Southern African Development Community (SADC) comprises the following member states: Angola, Botswana, Lesotho, Malawi, Mauritius, Mozambique, Namibia, South Africa, Swaziland, Tanzania, Zambia and Zimbabwe. Its principal objective is to foster closer economic and political ties among its member states and prepare the ground for the establishment of an economic community. SADC was established by Treaty in 1992. ${ }^{1}$. In addition to the above mentioned objectives, the Treaty sets out cooperation among member states, the institutions of the community and the modalities for the achievement of its goals.

The SADC Treaty requires member States to cooperate in all areas necessary to foster regional development and integration on the basis of balance, equity and mutual benefit. Member States are also to coordinate, rationalize and harmonize their overall macro-economic and sectoral policies and strategies, programs and projects. ${ }^{2}$ This is to be done through appropriate institutions established by SADC. In article $21,{ }^{3}$ the Treaty lists a number of areas in which the signatories have agreed to cooperate. These are: (a) food security, land and agriculture; (b) infrastructure and services; (c) industry, trade, investment and finance; (d) human resources development, science and technology; (e) natural resources and environment; (f) social welfare, information and culture; and (g) politics,

* LL.B. Zambia, LL.M (Harvard), D.Phil. (Oxon), Advocate of the Supreme Court of Zambia, Visiting Professor of Law, Cornell Law School.

1 Treaty of Southern African Development Community, Windhoek, August, 1992. The Treaty, after citing the objectives previously enunciated in the "Southern African Toward Economic Liberation - A Declaration by the Governments of Independent States of Southern Africa made at Lusaka, 1 April, 1980", establishes the SADC.

2

SADC Treaty, ibid, article 21 (1) (2).

3 SADC Treaty, ibid, article 21 (2). 
diplomacy, international relations, and peace. ${ }^{4}$ The list does not include the harmonization of law as one of the areas. We believe that legal integration is critical to the process of integration. It would promote intra regional trade and consolidate economic and political integration. This paper will therefore make a case for the inclusion of the unification of law in the SADC States, especially trade laws, among the areas of cooperation for SADC.

Conflicts and divergences arising from the laws of different SADC States in matters relating to trade, arbitration, enforcement of judgments will rank among the major barriers to intra regional cooperation and integration that SADC countries will confront as they move towards establishing a free trade are in the region. The membership of the Community represents at least three main legal systems, namely, the Common law, Roman-Dutch law and Civil law. ${ }^{5}$ Each, in turn, comprises many different systems of law, especially including traditional customary laws. ${ }^{6}$ Every country has its own legal traditions, legal thought, method of law-making and its own process of judicial determination of disputes. The achievement of several of the objectives of the Treaty will require the taking of legal measures to eliminate customs duties and adoption of a common external customs tariff and to eliminate non-tariff barriers to trade. Among the problems that would probably require immediate attention in the free trade area are many related to the implementation of these provisions.

The negotiations and regulations for the reduction of tariffs will inevitably be complex. Implementation will require the development of normative rules to give effect to the decisions. These will, in turn, have to be assimilated into the laws of member States. Thus, a greater effort will be required in the harmonization of community trade laws such as laws relating to bankruptcy, negotiable instruments, arbitration, sales contract, carriage of goods by sea, rail and road and many others. This implies the necessity to create a mechanism or a body with a clear mandate and

$4 \quad$ SADC Treaty, ibid, article $21(3)(a)(b)(c)(d)(e)(f)$ and(g).

5 South Africa, Lesotho, Zimbabwe, Namibia and Swaziland (Roman-Dutch); Angola and Mozambique (Civil Law) and Zambia, Tanzania and Mauritius (Common Law). See, M. Ndulo, The United Nations Convention on Contracts for the International Sale of Goods (1980) and the Eastern and Southern African Preferential Trade Area, 3(2) Lesotho Law Journal, (1987) p.127.

6 The Legal system of most African States follows the colonial pattern. This is as a result of European conquest. See, Kwame Opoku, "Legal Pluralism and Conflicts of Laws", The Law of Marriage in Ghana a Study in Legal Pluralism, (1976), p. 1; Antony Allot, New Essays in African Law, (1970); and Lawrence Church, "The Common Law in Zambia", in Law in Zambia, edited by Muna Ndulo, (1984). 
capacity to undertake the complex task of harmonizing community trade laws, which could spearhead the creation of the physical, technical and legal infrastructure that would support regional exchanges in goods, services, labour, and capital. It is argued in this paper that this could be done by designating the unification of law as one of the areas of cooperation among members of the Community and the working out of an institutional framework, which is in tandem with SADC working methods, to deal with the matter.

\section{B. ECONOMIC INTEGRATION IN AFRICA: SOME GENERAL CONSIDERATIONS}

Regional economic integration is generally seen by many African development economists and the Lagos Plan of Action, 1980, as a vehicle for enhancing economic and social development of the African countries. ${ }^{7}$ The Lagos Plan of Action underlined Africa's objective of attaining a more self-sufficient and more economically integrated continent by the year 2000 through, inter alia, the accelerated process of regional economic integration. ${ }^{8}$ The idea is reinforced by the relatively successful experience of integration among European States in the European Union and other promising integration schemes such as NAFTA. Development experiences and achievements in these integration schemes have shown that economic cooperation is an important and potentially effective means of facilitating social and economic development. ${ }^{9}$ The growing need for economic

7 See, generally, "Sub-Saharan Africa: From Crisis to Sustainable Growth", World Bank Report (1989); "African Alternative Framework to Structural Adjustment Programmes for Social-Economic Recovery and Transformation (AAF-SAF)", United Nations Economic Commission for Africa (E/ECA/CM.15/6/Rev.3); Peerre-clas ver, "Development Strategies - Lessons from Experience", in African Leadership Forum,(Ota, Nigeria), 1988 and Olayiwola Abegunrin, Economic Dependence and Regional Cooperation in Southern Africa: SADC and South Africa in Confrontation, 1989.

8 The Lagos Plan of Action was adopted in 1980 and its central theme was regional integration. It called for the establishment of the African Economic Community by the year 2000. See, Organization of African Unity, Lagos Plan of Action for the Implementation of the Monrovia Strategy for the Economic Development of Africa (Lagos, April 1981). The SADC Treaty in its preamble states that, the Southern African States, in estabhshing SADC took into account the Lagos Plan of Action and the Final Act of Lagos of April 1980, and the Treaty establishing the African Economic Community at Abuja, concluded on 3 June, 1991.

9 "Cooperation versus Integration: The Prospects of the Southern African Development Coordinating Conference (SADC)" - Occasional Papers of the German Development Institute (GN) No. 77. 
cooperation in Africa arises from both external and internal circumstances. Internally, there is increased realization of the smallness of African economies, uneven and untapped resources, small size nature of African markets and distortions in the pattern of economic activity which impede development purely on a national scale. Externally, the increasing internationalization and globalization of the world economy creates the necessary impetus for economic integration.

Development economists argue that regional cooperation can help promote a more complementary and sustained development of member countries of a community. ${ }^{10}$ This can come about through the reinforcement of the regional infrastructure, the development of a more efficient system of payments, greater access to credit, a greater awareness of each others' products and economic agents operating in the different countries that comprise the community and, above all, through a growing technical complementarity and a greater development and integration of the productive sectors of the countries involved. The SADC experiment is important for Africa for if it succeeds it may raise hopes for the whole continent and lessen the perception that Africa is a basket case. There is urgent need to reverse the endemic economic decline of Africa. The latest UNCTAD Trade and Development Report (1995) concludes that, among the developing regions, Africa has yet to show tangible signs of a strong recovery and sustained growth, despite several years of implementing Structural Adjustment Programmes (SAPs). ${ }^{11}$

The report further states that the economic situation in Africa remains precarious and worrying, and contrasts sharply with the trends in Asia and Latin America. The region's share of both world output and trade has continued to shrink, whereas its share of world population has continued to rise. In addition to the adverse impact of political instability, ethnic conflicts and vagaries of the weather, economic performance in the region continues to be characterized by low productivity, inefficient management, failure to diversify from a narrow production and export base, and economies that are highly vulnerability to the external economic environment. ${ }^{12}$ It is of course realized that promoting regional cooperation

10 Rose Mtengeti-Migiro, Institutional Arrangements for Economic Integration in Eastern and Southern Africa: a Study of SADCC and the PTA with Experiences from the EEC, 1992; See also Lagos Plan of Action, (1980) and Olayiwola Abegunrin, op. cit., supra, Chapters 1 and 2.

11 UNCTAD, Trade and Development Report, 1995, p. 1.

12 UNCTAD, op. cit. supra, p. 1. The Report observes “ In Africa, Structural Adjustment programmes continued to bring only a modest improvement in the growth rate. Longterm development performance remains depressed by commodity dependence, poor 
and integration can not alone help solve Africa's lack of economic development. The debt burden will have to be resolved and the concentration of investment in extractive industries will have to be shifted to more productive enterprises for long-term gains. In recognition of this, SADC's approach to integration is not based on the orthodox trade liberalization strategies. Rather, its strategy is based on the development of infrastructure and production. SADC from its inception, has argued that reduction or even elimination of tariffs to trade does not always yield increased trade, in the absence of tradable goods. In its view the greatest single barrier to trade in Southern Africa is lack of production and hence the focus on cooperation in several areas of production and investment in its programmes. ${ }^{13}$

\section{THE HISTORY OF SADC}

The Southern African Development Community was established in pursuance of a declaration made by the Heads of State and Governments of Southern African states at Windhoek, in August 1992 ${ }^{14}$. The declaration was entitled "Towards a Southern African Community". 15 In it, the signatories, affirmed their countries" commitment to establish a development community in Southern Africa. The idea developed out of an earlier Southern African organization created by the Front Line States, i.e. the Southern African Development Coordinating Conference (SADCC). ${ }^{16}$ This earlier organization grew out of a response to South Africa's proposal for the formation of a Constellation of Southern African States (CONSAS) in 1979. As part of what was termed the policy of total onslaught designed to deal with the threat posed by liberation forces to apartheid South

infrastructure, over-indebtedness, low levels of domestic investment and caution by foreign investors as well as by political instability and conflicts."

13 The Economist Intelligence Unit, "SADCC in the 1990s: Development on the Front line", Special Report, No. 1158, (1989).

14 Treaty of the Southern African Development Community, Windhoek, August, 1992.

15 "Towards a Southern African Development Community", Declaration made by Heads of State and Government of Southern Africa, Windhoek, August, 1992.

16 SADCC's formation had been a subject of serious discussion since 1978, and was promoted particularly by the late Botswana President, Sir Seretse Khama. It grew as an economic extension of the Front line States (Angola, Botswana, Mozambique, Tanzania, Zambia and Zimbabwe). See, Economist Intelligence Unit, SADCC in the 1990s, op. cit., supra; see also, Rose Mtengeti-Migiro, op. cit., supra, Chapter 2; and also Margaret Lee, SADCC the Political Economy of Development in Southern Africa, 1989, Chapter, 1. 
Africa's survival, South Africa proposed the formation in Southern Africa of an economic forum for spearheading economic development in the region. The idea was, without doubt, an attempt by South Africa to contain the rising opposition to the repugnant system of Apartheid by seeking the cooperation of Southern African States in ensuring South Africa's military and economic domination of the region. The proposal was rejected by South Africa's black ruled neighbours. ${ }^{17}$ Instead the South African efforts inspired the black ruled States to seek ways and means to counter South Africa's efforts and its domination of the region.

In July 1979, Southern African States agreed on a policy of regional cooperation to counter South Africa's machinations. This agreement, led to the signing of the Lusaka Declaration on Economic Liberation on 1 April, 1980.18 At the same meeting, the Southeru African States agreed to form SADCC. ${ }^{19}$ The objectives of SADCC were to break South Africa's economic domination of its neighbours and simultaneously create conditions for sustainable economic development within Southern Africa. It must be remembered that during this period, South Africa used its economic and military muscle to de-stabilise those countries in Southern Africa that were playing host to and supporting liberation movements. At a summit meeting in Arusha Tanzania in 1991 the member States of SADCC stated the principal objectives of the Organization in the following terms:

"The gradual reduction of economic dependence particularly, but not only, on the Republic of South Africa; forging of links to create genuine and equitable regional integration; the mobilisation of resources to promote the implementation of national, interstate and regional policies; and concerted action to secure international cooperation within the framework of their strategy for economic liberation." 20

17 Margaret Lee, op. cit., p. 3; See also Douglas Anglin, "Economic Liberation and Regional Cooperation in Southern Africa: SADCC and PTA", International Organization, vol.37 no. 4, 1983 and R. Davis and D. O'Meara, "Total Strategy in Southern Africa: An Analysis of South African Regional Policy Since 1978", Journal of Southern African Studies, vol. 11, No. 2, 1985.

18 Economist Intelligence Unit, SADCC in the 1990s, op. cit., supra; See also Southern Africa: Towards Economic Liberation: a Declaration by the Governments of Independent States of Southern Africa Made at Lusaka on the 1st of April, 1980 and Memorandum of Understanding of the Institutions of the Southern African Development Coordination Conference, Harare, $20 \mathrm{July}, 1981$ as amended (in Article 111, para. 2) in Gaborone on 22 July, 1982.

19 The founding members of SADCC were: Angola; Botswana; Lesotho, Malawi; Mozambique; Swaziland; Zambia and Zimbabwe.

SADCC Annual Meeting, Arusha, Tanzania, 1991. 
SADCC operated with a small secretariat and for most of its early existence run on an informal basis, that is without a formal treaty. Within the context of its objectives - to counter South African influence - SADCC had major successes such as the rehabilitation of the railway line from Zimbabwe to Beira in Mozambique, the upgrading of port of Beira for handling and ferrying cargo and merchandise to and from Zimbabwe and Malawi and the improvement of telecommunications in the region. ${ }^{21}$ It also improved air, satellite and electricity power generation links amongst its members. ${ }^{22}$ It further established a number of regional research institutes in the field of agriculture and transport. In 1992-1993, it successfully coordinated the importation and procurement of grain into the region during a period of severe drought. ${ }^{23}$

By 1992, however, it had become apparent that Apartheid would soon end in South Africa. Members of SADCC reviewed the future of the organisation im order to position it for a new role in a Southern Africa with a non-racial democratic South Africa. In August 1992, as pointed out earlier, the SADCC States adopted a declaration entitled "towards a Southern African Development Community" in which they agreed to form an economic community of Southern African States. ${ }^{24}$ At the same meeting, the SADCC member States, adopted a treaty establishing the Southern African Development Community (SADC). The Treaty changed the name of the Organisation from Southern African Development

21 See , "Implementing the SADCC Programme of Action", A Joint Study by the SADCC Secretariat and OECD Development Center of Structures and Procedures in Development Cooperation, Gaborone/Paris, 1988; "Cooperation Between Electricity Utilities in the SADCC Region"; Proceedings of the Seminar on SADCC Energy Sector, Harare, 12-16, December 1984, "Electricity in the SADCC Region, Status and Future Projects on Regional Cooperation", Proceedings of a Workshop held in Mbabane, 6-9 March, 1988.

22 "Telecommunications: 10 Year Development Plan", Summary of Proceedings of SATCC, Maputo, 1987. See also "Transport and Communications, Rehabilitation, Harmonization and Modernization in The SADCC African States", Working Paper presented to a Joint Conference Sponsored by the International Transport Federation, the Friedreich Egbert Foundation and SADCC Transport Trade Unions, Harare, 23-27 September, 1985.

23 "Regional Seed Production and Supply Project", Record of the Meetings of the SADCC Technical Experts to Review the Draft Report, Juliasdakle, Zimbabwe, 11-15 April 1988; see also Country Profiles SADCC Food Security Sector, Harare, 1988; SATUCC, Gaborone, 1985; and Regional Cooperation in Shipping, Phase A, Final Report, Project 301, by ISTEE , University of Trieste, Italy SACC, Maputo, 1986.

24 The Treaty of the Southern African Development Community, August, 1992, Article 1. Article 3, States that SADC shall be an international organization, and shall have legal personality with capacity and power to enter into contract, acquire, own or dispose of movable or immovable property and to sue and be sued. 
Coordinating Conference to Southern African Development Community and its mission from that of reducing dependence on South Africa to one of creating an economic community in Southern Africa. ${ }^{25}$ South Africa joined SADC in August 1994. Mauritius became its 12th member in August 1995. The admission of any State to the membership of SADC is effected by a unanimous decision of all SADC member States at a SADC summit.

The SADC region contains a population of about 135 million with a gross national domestic product of $\$ 170$ billion. It is rich in agriculture, mineral and energy resources. Rivers such as the Zambezi, Linyanti, Okavango, Kwando and Orange as well as lakes such as Malawi and Mweru and numerous dams such Kariba, Kunene and Cabora Bassa, have enormous potential for hydroelectric power generation. These largely untapped water supplies could also be used for irrigation and agricultural production to meet the demand of regional and export markets. In order to create viable agro-industries, for which enormous scope exists, advanced technology and better agricultural and water resource management are necessary. Abundant reserves of diamonds, gold, coal, iron ore, copper, lead, bauxite, nickel, and many other minerals give rise to much of the region's employment and generate considerable foreign currency earnings. ${ }^{26}$ While SADC has this tremendous potential for economic development, because of a lack of technology, coupled with undercapitalisation in the region, its resources are largely untapped.

As a result Southern Africa remains beset by a range of critical problems. There is chronic underdevelopment and attendant poverty, illiteracy, malnutrition and inadequate provision of social services for the people of the region. Efforts to address these problems are inhibited by balance of payments deficits, an acute debt crisis affecting most of its members and an unfavourable international economic climate. ${ }^{27}$ There is definitely a great need for coordination in the attraction of foreign investment and technology to harness the resources of the region. There is also need for regional coordination on matters of development to maximise economic benefits to SADC member countries. The SADC framework of cooperation must make concerted efforts to exploit its natural resources for self reliance and sustained economic development. Successful regional

\section{Ibid, article 5.}

26 See, Margaret Lee, op. cit., supra; generally and J. Haarlov, Regional Cooperation in Southern Africa, Central Elements of the SADCC Venture, CDR Research Report No. 14, Copenhagen 1988 and UNIDO, Investors Guide to SADCC Countries, Vienna, 1986.

27 Minnie Venter (ed), Prospects for Progress: Critical Choices for Southern Africa, 1994, p.1. 
integration will engender a major re-orientation of economic activities and the establishment of institutions to promote regional trade and investment. Initially SADC was composed of countries with different economic orientations and political ideologies. A number of countries in the region followed the socialist model while others followed the capitalist model. ${ }^{28}$ With the demise of the cold war, this situation has changed. All SADC member States embrace the free market system and welcome the role of private investment in the development of their economies and all but one have held democratic elections or are committed to democratic governance. The region is wcll connected by rail and road networks, an important asset and facilitator of the movement of goods and services.

\section{OBJECTIVES OF SADC}

The objectives of SADC as stated in article 5 (1) of the SADC Treaty are to: (a) achieve development and economic growth, alleviate poverty, enhance the standard and quality of life of the peoples of Southern Africa and support the socially disadvantaged through regional integration; (b) evolve common political values, systems and institutions; (c) promote and defend peace and security; (d) promote self-sustaining development on the basis of collective self-reliance, and the interdependence of member Sates; (e) achieve complementarity between national and regional strategies and programmes; (f) promote and maximize productive employment and utilisation of resources of the region; (g) achieve sustainable utilization of natural resources and effective protection of the environment and (h) strengthen and consolidate the long standing historical, social and cultural affinities and links among the peoples of the region. ${ }^{29}$

The strategies for achieving these goals are set out in Article 5 (2). SADC is to: (a) harmonize political and socio-economic policies and plans of member States; (b) encourage the people of the region and their institutions to take initiatives to develop economic, social and cultural ties across the region, and to participate fully in the implementation of the programmes and objectives of SADC; (c) create appropriate institutions and mechanisms for the mobilisation of requisite resources for the implementation of programmes and operations of SADC and its

28 See, Margaret Lee, op. cit., supra, Chapter 3. The East African Community is said to have collapsed in part because of differing economic policies, see Rose MtengetiMigiro, op. cit., supra, p. 31.

Treaty of the Southern African Development Community, Windhoek, 1992. 
institutions; (d) develop policies aimed at the progressive elimination of obstacles to the free movement of capital and labour, goods and services and of peoples of the region generally among member States; (e) promote the development of human resources; (f) promote the development, transfer and mastery of technology; (g) improve economic management and performance through regional cooperation; (h) promote the coordination and harmonization of international relations of member States; and (i) secure international understanding, cooperation and support, and mobilise the inflow of public and private resources into the region. ${ }^{30}$

To give the Treaty practical effect, provision is made for States to negotiate a series of protocols which spell out the objectives, scope of, and institutional mechanisms for cooperation and integration in designated areas. On approval, the protocols become an integral part of the SADC Treaty. ${ }^{31}$ Member States undertake to adopt adequate measures to promote the achievement of the objectives of SADC, and agree to refrain from taking any measures likely to jeopardise the substance of its principles, the achievement of its objectives and the implementation of the provisions of the SADC Treaty. Member States are required to accord the Treaty the force of national law. This provision, in itself, is not however sufficient to make the Treaty applicable in a domestic jurisdiction. Member States would have to pass implementing legislation to achieve this result. The situation in States where Constitutions make Treaties, once entered into by the State, applicable in the domestic jurisdiction might be different. That situation prevails only in South Africa under its new Constitution. ${ }^{32}$

As can be seen from its objectives, SADC is to be a customs union seeking to establish free trade within its internal market and is intended to develop into an economically and politically integrated community. Central to this objective is, the lifting of internal tariffs and non tariff barriers, free movement of persons, capital and establishment of common transport and communications policies, standardisation of trade practices and so on in order to enhance a faster rate of economic development. In the European Union, there were two characteristics of the common market programme which were mstrumental in ensuring that the objective of a common market was reached and which should be noted by SADC. The first was to reduce tariffs on "across the board" basis. This principle meant that tariffs were to be reduced, not only on commodity by commodity approach but on all

\footnotetext{
30 Ibid.

31 Ibid, article 22.

32 Ibid, article 6. See the Constitution of the Republic of South Africa, adopted in December 1996 and came into force on 3 February 1997.
} 
goods at once. This approach was important since it ensured that the elimination of internal barriers was taken out of the hands of the negotiators, and by being formulated in an ex parte fashion the programme came into effect automatically. Secondly, there was a time table according to which customs duties and quota restrictions or measures of equivalent effect were to be eliminated. It was perceived that a timetable, laid in advance and agreed to by all parties, would be necessary to guarantee that the economic integration process was not unduly disrupted. ${ }^{33}$ This indeed paid off when the Community managed to remove tariff and quota restrictions ahead of the originally envisaged schedule.

The freedom of establishment and the freedom to supply services are an important aspect of economic integration. They cover the right of non-wage earners (self employed) to establish companies or firms and the freedom to offer services. In as far as individuals are concerned, the right of establishment implies the right to take up and pursue activities as a selfemployed person in another country. The right to provide services extends to citizens of member countries who are established in a country other than that of the person for whom the services are intended. The SADC Treaty recognises the importance of this to economic integration by categorically prohibiting discrimination between nationals of member States and asking member States to take measures that abolish all restrictions on the freedom of establishment. ${ }^{34}$ The freedom of movement of capital is complementary to that of movement of goods, persons and services but it has a special connection with the right of establishment. It would be useless if a person should only have the right to set up an economic activity in another member country but denied the right to transfer capital to another country to enable that person to acquire the necessary premises and operational facilities required for the activity.

It can be seen, from the areas of cooperation outlined in the Treaty, that SADC is not simply a trading organisation or a mechanism restricted to the promotion of cooperation in production based on the creation of a common market. In addition to the integration of national markets and cooperation in production, the States joining the Community undertake to cooperate with each other in certain functional areas as well e.g. social, political, diplomatic, sports and regional security. ${ }^{35}$ The member States intend to strengthen and consolidate the long standing historical, social and cultural

33 See, Rose Mtengeti-Migiro, op. cit., supra, p. 21.

34 See, Treaty of the Southern African Development Community, supra, article 6, and 5 (2) (d).

35 Ibid, article, 5 (1) (a), (b), (h) and (5) (2) (b). 
affinities and links among the peoples of the region and to harmonise political and social policies among themselves. The SADC States have many traditional links. They all recently emerged from colonial oppression; most of them after bitter and protracted liberation wars. They assisted each other in the liberation wars. The ethnic groups in many of the SADC States overlap. The SADC strategy of encompassing non-economic activities among its areas of cooperation is a realization that successful integration is based on the twin foundations of economic and political integration.

\section{E. SADC INSTITUTIONS}

The treaty establishes six institutions for the community. These are: the Summit of the Heads of State or Government; the Council of Ministers; Commissions; the Standing Committee of Officials; the Secretariat and the Tribunal. ${ }^{36}$ The Summit is the supreme policy making body and is responsible for the overall policy direction and control of the functions of SADC. It adopts the legal instruments for the implementation of the provisions of the Treaty. ${ }^{37}$ The decisions of the Summit are by consensus. The Council of Ministers oversees the function and development of SADC and the implementation of the SADC policies and programmes. It advises the Summit on matters of overall policy and the development of SADC, approves policies, strategies and work programmes of SADC. ${ }^{38}$ The Commissions provided for in the Treaty, when constituted, are to guide and coordinate cooperation and integration policies and programmes in designated areas. ${ }^{39}$ The Commissions are composed of experts responsible for planning and developing strategies within each of the SADCC sectors. Commissions are created by the Council of Ministers. They are responsible for running each sector or sub-sector.

The real functioning units of SADC are the Standing Committees of Officials. ${ }^{40}$ They consist of one permanent secretary or an official of equivalent rank from each member State, preferably from a ministry responsible for economic planning or finance. The Standing Committees make recommendations to the Council of Ministers, and the Council in turn makes recommendations to the Summit. They function more or less as a

\footnotetext{
36 Ibid, article, 9.

37 Ibid, article, 10.

38 Ibid, article, 11.

39 Ibid, article, 12.

40 lbid, article, 13.
} 
technical advisory Committee to the Council of Ministers. The last major institution of SADC is the Tribunal. It is constituted by article 16 of the Treaty. Among its tasks, is to ensure adherence to and the proper interpretation of the provisions of the Treaty and to hear disputes in relation to the Treaty. Its composition, powers functions, procedures are to be prescribed by a protocol. For an article governing an institution of such great significance, this article is unsatisfactory and needs to be clarified. Article 16 (5), for instance, states that the Tribunal's decisions are binding on member States. This is somewhat confusing as article 16(4) on the other hand states that "the tribunal shall give advisory opinions on such matters as the Summit or the Council may refer to it." It is not clear which decisions are binding and who can bring actions before the Tribunal. Such an important matter as who has standing before the Tribunal should not be left to inference or a subsequent protocol.

SADC operates on the basis of a highly decentralised structure. Sectoral programmes, based on areas of cooperation, are coordinated by a specific member State as may be decided by the Summit. The current allocation of responsibilities to individual countries is as follows: Angola - energy; Botswana - livestock production and animal disease control; Lesotho environment, soil and water conservation and land utilisation; Malawi fisheries, forestry and wild life; Mauritius - tourism; Mozambique culture, information, transport and communications; Namibia - marine fisheries and resources; Swaziland - manpower development; Tanzania industry and trade; Zambia - mining, labour and employment; Zimbabwe food security, agriculture and natural resources; and South Africa finance, trade and investment. ${ }^{41}$ Once SADC has assigned coordination to a particular country the sector-coordinating country designates a relevant ministry in its Government. The ministry sets up a sector-coordinating unit for that purpose. Each host country is required to service its unit in terms of competent manpower, provision of office space and meeting running costs. In this way, the administrative burden of coordination, is shared without the creation of formal and large institutions. SADC operates largely through committee meetings comprising officials of member States, relevant ministries and technical experts, all of whom make part of the sector task force. Policies, programmes, possible regional projects are all discussed in

41 See, Haalov, op. cit., supra. And also Wolfgang Zehender, "Cooperation Versus Integration: The Prospects of the Southern African Development Coordinating Conference (SADCC)", Occasional Papers of the German Institute, (GN) No. 77. There have been additions since the admission of Southern Africa and Mauritius. Others argue that this approach to organization weakens SADC as it relegates the running of SADC affairs to increasingly fragile state structures. 
these meetings and information shared. Thereafter, representations are made to the Council of Ministers, which finally decides which projects should be included in the SADC regional pool. The sector-based Commissions act as technical advisors to member States, on the one hand; and on the other, they act as links between member States and co-operating partners. This structure and the method of operation seems to have worked well up to now. Nevertheless, this seemingly organisational strength of SADC at this stage of its development, might have to be adjusted as the work load of the Organisation increases. Clearly there will be need to establish institutions that can administer the burden of work that is bound to be generated by the process of integration.

The approach in SADC can be contrasted with that of the European Union. The European Union countries did not sign the EU treaty simply to create mutual obligations governed by the law of nations, rather, they limited their sovereign rights by transferring them to institutions over which they had no direct control. ${ }^{42}$ Furthermore, it was not only member governments which were bound by the new rights and obligations, but also their citizens who became subjects of the Community. They thus created a "supranational" as opposed to an international body of law and institutions which stood above individual national States. In contrast the SADC Treaty does not create supranational organs. As such, implementation of the relevant objectives, depends entirely on individual member States. ${ }^{43}$

\section{F. OBSTACLES TO INTEGRATION IN AFRICA}

In Southern Africa, like in the rest of Africa, there are major obstacles to overcome in any move towards complete trade liberalization and market integration. Integration is not a new phenomenon in the region. The federation of Rhodesia and Nyasaland and the South African Customs Union both predated SADC. The record of the integration process in Africa to date, does not give much room for optimism. There are currently several African integration schemes. These include the West African Economic Community (CEAO), Common Market of East and Southern African States (COMESA), and Economic Community of West African States (ECOWAS $^{44}$ to mention just a few. For most of these groups

42 See, Rose Mtengeti-Migiro, op. cit., supra, p. 20.

43 Treaty of the Southern African Development Community, op. cit., supra, article 6.

44 Wolfgang Zehender, op. cit., supra; see also Olayiwola Abegunrin, op. cit., supra. 
achievements have been minimal and for the most part short-lived. ${ }^{45}$ These schemes continue to lack an effective regulatory framework to implement community goals and tariff and non tariff barriers have not been reduced.

The tempo and mode of integration basically depends on the development strategies and external linkages adopted by the countries participating in the process. There are additional problems that make economic integration difficult in Africa. The economic nationalism that was strong at independence has left its mark. Many countries seem to go into economic integration agreements without any intention of parting with some measure of sovereignty. Further, there is usually a lack of national institutions and structures to implement integration programmes. Some Governments lack the human and economic capacity to implement the process. Membership in regional groupings has been often sought as a sign of being a good African and as a way to obtain external development assistance rather than representing a real commitment to integration. Membership in an economic community has serious long term implications for the countries involved. It entails very close cooperation with one's neighbours. Traditional rivalry and differences among countries often impede the integration process. States must learn that decisions relating to economic integration adopted by organisations to which they belong need to be fully and immediately implemented. Differences in linguistic, political, legal and administrative systems must be addressed and solutions to them sought. There is the problem of low priority accorded to the implementation of integration programs vis-à-vis national ones which are very often supported and financed by influential international institutions such as the Interuational Monetary Fund (IMF) and the World Bank. For example under the structural adjustment programs in place in most African countries, including the ones in Southern Africa, domestic considerations take precedence over sub-regional integration preoccupations. ${ }^{46}$

There is the inadequacy of the regional economic infrastructure to support economic integration. For instance, one of the major constraints on the growth and development of inter-African trade has been the inadequacy

45 See, Rose Mtengeti-Migiro, op. cit., supra, chapter 4, pp. 112-148; See also, "PTA Trade and Development Strategy: Market Integration and Economic Transformation for Sustainable Growth", adopted by the Heads of States and Government of the Preferential Trade Area (PTA) at the Tenth Summit held in Lusaka, Zambia, 30-31 January, 1992.

46 Ona Soleye, "African Alternative Framework to Structural Adjustment Programme for Socio-Economic Recovery and Transformation", Paper prepared for presentation at the International Conference on "the Regulation of Trade and Investment in an Era of Structural Adjustment - The African Experience" Nigerian lnstitute of Advanced Legal Studies, Lagos, Nigeria, September 4-7, 1989. 
of the payments, financial, communications and transport systems in place in most African countries to support the process. ${ }^{47}$ Increased Southern African trade will need finance and financial institutions such as banking networks providing letters of credit, export credits and other financial services. There is the problem of diversified currency exchange regimes and payment restrictions that prevail in Africa. Integration will require the adoption of collective policy measures to facilitate the liberalization of payment and exchange restrictions and to enhance the convertibility of national currencies. The hostile world economic environment has meant that many African countries are preoccupied with the economics of short term recovery to the detriment of regional integration. Most African regions lack an acclaimed integration leader with impeccable credentials such as a domestic economic track record of monetary and financial stability, diligent implementation of community programmes, a willingness to assume requisite responsibilities and a dominant position in regional trade and finance. In the case of ECOWAS, for example, Nigeria, would have been the natural choice to provide the leadership in the Organisation. Unfortunately, Nigeria has such serious internal problems that it is not at present in a position to play that role.

The political environment prevailing in countries joined together as a community is also a critical factor in the success of the integration process. ${ }^{48}$ The environment must be right and conducive to integration for an economic community to succeed in achieving its goals. Economic cooperation and integration flourish better in an environment that is politically peaceful and stable. The examples of successful economic integration underscore this point. They are all predicated primarily upon a common outlook on political, social and economic affairs. The locus classicus for such peace and stability is the freedom for the individual and good governance. Democracy is the ultimate guarantee of freedom of movement, goods, services and capital. There is also need for the private sector and civil society in Africa to do more to pressure Governments to move along on the path to integration. They can organise themselves on regional lines and fight for good governance and the observance of human rights in the region. Business organisations in Europe have often been at the forefront of pressuring their Governments to move on European

47 See, "Commercial Banking in the SADCC Region: The Quest for a Role", Proceedings of the First Conference of Commercial Banks of the SADCC Region, held at the Arusha- International Conference Center, 13-17 August 1984; see also, C.D. Mysua, The Quest for a Role of Commercial Banks in Fostering the SADCC Initiative, 1984.

See, Olayiwola Abengurin, op. cit., supra, p. 45. 
integration. Integration will require addressing complex organisational issues. It will also require finding ways to strengthen the commitment of governments and to draw in a range of other key stakeholders. In the final analysis, only if regional organisations can organise a popular constituency in favour of the goals of a regional programme, can the process be expected to develop real momentum. ${ }^{49}$ The SADC Treaty recognises this and to this effect provides in article 23 that: (a) in pursuance of the objectives of the treaty, SADC will seek to involve fully, the peoples of the region and nongovernmental organizations in the process of regional integration and (b) shall cooperate with, and support the initiatives of the peoples of the region and non-governmental organisations, contributing to the objectives of the Treaty in the areas of cooperation in order to foster closer relations among the communities, associations and peoples of the region.

\section{G. THE NEED TO HARMONISE SADC TRADE LAWS}

As we have observed earlier, the harmonisation of trade laws and commercial practices is an important ingredient of regional integration, without which meaningful economic integration cannot be achieved. Economic integration needs a legal framework to foster and support it. It is widely recognised that conflicts and divergences arising from the laws of different States in matters relating to international trade constitute an obstacle to the development of that trade. ${ }^{50}$ The existence, in SADC, of widely accepted trade laws and commercial practices would eliminate a number of problems which usually plague intra regional trade. One of the problems traders face is the diversity of national laws and the complexity of the rules of private international law for determining which system applies to their transactions, which, even if based on the choice of the parties, would have to contend with limitations imposed by individual

49 See, Rose Mtengeti-Migiro, op. cit., supra, p. 167. She observes that "invariably economic integration has been taken to be the business of governments". She recommends that integration must be supported by (a) building a tradition of integrative spirit (b) fostering people to people contacts. For integration to prosper there must be popular participation in the process.

50 The study that led to the establishment of UNCITRAL referred to difficulties faced by parties engaging in international commercial transactions as a result of the multiplicity of and divergences in national laws and recommended a new UN organ to systematise and accelerate the process of harmonisation and unification of international trade law. See "Progressive development of the law of international trade: Report of the Secretary-General", Official Records of the General Assembly, Twenty-first Session, Annexes, agenda item, docs.A/6396, Add.1. 
States. Presently within the region, in a commercial dispute, the parties cannot always be certain which law will apply. This makes traders less inclined to enter into intra regional commercial transactions. If the parties in an intra regional business transaction come from different States and are therefore accustomed to different legal systems, the governing law is going to be unfamiliar to one of the parties. This, in turn, may also discourage parties from entering into intra regional trade..$^{51}$ The absence of uniform commercial rules makes the outcome of litigation unpredictable and to some extent dependent on the court and place of hearing of the case. The problem is compounded by the fact that these laws are often inadequate to deal with issues arising from intra regional transactions since they were usually designed to regulate domestic transactions. ${ }^{52}$.

In the absence of a supranational, all-embracing mercantile legal system, intra regional traders can, and do, choose between the national legal systems by indicating in the contract the one which they want to govern the contractual relationship. The concept of party autonomy is common to most systems of law and permits the parties, within limits, to choose the proper or governing law of a contract. A choice of law clause, however, is not always a practical solution to the problems presented in intra regional trade. Very often contracts fail to specify which law applies because of an impasse over this delicate question, or because it is overlooked in the need for speed in concluding a contract. In these cases, a buyer or seller will not be able to determine which law will apply until he or she completes a detailed conflicts of law analysis to determine which law has the closest relationship to the transaction. When this analysis suggests that the law of a given State other than his or her own may apply, the buyer or seller must then go through the difficult process of researching the law of the State to determine his or her rights and obligations. This is particularly problematic in Africa because access to another State's legal materials is very difficult. Harmonisation of commercial laws and practice would ensure that whether litigation is in State $\mathrm{X}$ or in State $\mathrm{Y}$, the courts seized of the matter will apply the same governing law.

51 Ibid.

52 From a study on the arbitration laws of the member States of the PTA it was found that the national laws studied did not address themselves to international commercial arbitration because they were basically designed for arbitration of domestic commercial disputes. See Report of the Seminar on International Trade Law, Preferential Trade Area for Eastern and Southern African States/United Nations Commission on International Trade Law, Regional Seminar, Maseru, Lesotho, 20-30 July, 1988, p. 18. 
In addition, a number of issues arise in intra regional trade which do not present themselves in domestic commercial transactions. The parties involved in the transaction may have had no previous contact with each other. In a sales contract, for instance, this may mean that the seller is not familiar with the financial standing of the buyer. He or she has less opportunity for inspecting the goods before purchase or delivery. The delivery of the goods into the possession of the buyer, in intra regional trade, often necessitates carriage of goods by air, rail, road or sea over several national boundaries. Intra regional trade will require insurance and payment arrangements that involve arrangements covering more than one State. In many SADC jurisdictions, it may be difficult to find well developed legal rules governing some of these aspects of commercial transactions. Several areas of law can be identified as requiring significant progress towards harmonisation. These include: the law of sale of goods; the law relating to the supply and erection of plant and machinery in member States; laws relating to bills of exchange, bankers' commercial letters of credit and guarantees, investment protection, trademarks and franchising, licensing of technology, distribution agreements, agency contracts, bankruptcy, security interests, mergers and acquisitions; the law relating to electronic data interchange and the law of commercial arbitration. All these areas of the law play an important facilitating role to trade and if they are not harmonised, will tend to add to the cost of trade and impede intra regional trade.

\section{H. TECHN1QUES THAT CAN BE USED TO HARMONISE SADC LAWS}

Hitherto, there have been no efforts aimed at integrating or harmonising any branch of law in Africa and, consequently, no examples of the African experience can be used. The methods examined here have been used elsewhere in the world and it is suggested, may serve as examples in the SADC context. The integration of laws can be advanced by using a variety of methods, ${ }^{53}$ but closer analysis of harmonisation work elsewhere reveals that in essence three methods have been adopted to further the progressive unification and harmonisation of laws. The first is the introduction of normative rules devised and elaborated within the framework of a treaty,

53 On the methods of international unification, see Report of the American Bar Association Special Committee on International Private Law (1961), p. 6 and United Nations Commission on International Trade Law, Yearbook, 1968-70, pp. 39-40. 
i.e., convention. The normative rules themselves could be of three different kinds. One kind is the approach of adopting detailed uniform provisions for the substantive resolution of problems. Another approach is that of adopting conflicts of law rules, which envisages not uniform substantive rules but uniform reference to a particular body of law in all cases, i.e. rules relating to choice of competing substantive laws applicable to a particular transaction, and rules determining the competence of courts in particular litigation..$^{54}$ The third approach is the constitutional approach, which seeks to specify general uniform standards within which particular resolutions are possible. This is where, for instance, a treaty provides that States will enact the necessary legislation to implement, within specified limits, the policies embodied in the treaty. 55

The second method of harmonisation, which is, in effect, an alternative to the first, is the formulation of model laws to serve as guides for local adaptation and uniform laws to be incorporated by States into their legislation. The model law method has the advantage that it permits substantive uniformity without requiring, as a treaty normally does, exact equivalency. It does, however, have the disadvantage that in the process of national implementation the uniformity achieved with such difficulty at the time of the elaboration of the model law may be lost. The third technique is the formulation of commercial customs and practices, founded upon the usages of the coinmercial community with the aim of achieving standardisation. This would involve recommendations of standard practices, studies of national laws with a view to finding the minimum common rules that could be generally acceptable on a regional basis. 1llustrations of this third method are the Incoterms 1953 and 1990, the Uniform Customs and Practice for Documentary Credits prepared by the International Chamber of Commerce (ICC), the various General Conditions of Sale and Standard Forms of Contract sponsored by the Economic Commission for Europe (ECE) and the Civil Conditions of Contract 1987 developed by the Federation Internationale des Ingenieurs Conseils (FID1C). ${ }^{56}$

Essential differences exist between the methods described above. The first and second are applied by virtue of the authority of the State, whereas the third is founded upon the autonomy of the will of the parties who adopt the customs and practices as the regime applicable to the individual

\footnotetext{
54 See, Eck Hilding, The Swedish Conflicts of Laws (1965), p. 272.

55 See, United Nations Commission on International Trade law, Yearbook, op. cit., supra.

56 See, Federation International des Ingenieurs Conseils, Conditions of Contract for works of Civil Engineering Construction, (Parts I and II), 1987.
} 
transactions at hand. Experience in other regional economic communities has shown that each of these methods is essential to further the regional unification of trade law and commercial practices and, furthermore, that each complements the other. ${ }^{57}$ It is therefore evident that harmonisation of commercial laws and practices in the SADC region will require that all of the three methods described above should be actively pursued within the context of SADC.

In addition to the methods described above, the SADC treaty has empowered various organs of the Community to take legislative measures through the conclusion of protocols and make decisions in relation to the implementation of the Treaty. Article 10 of the Treaty, for instance, empowers the Summit to adopt legal instruments to implement and attain the objectives of the Treaty. It can delegate this power to the Council of Ministers or any other institution of SADC. The decisions of the Summit are binding on member States and organs of the Community. The other organ of the Community, the Council of Ministers, under article 11, has power to make recommendations to the Summit on any action aimed at attaining the objectives of the Community. It has power to define and add to the sectors of cooperation and allocate to member States responsibility for co-ordinating sectoral activities, or re-allocate such responsibilities. ${ }^{58}$

These are important powers which can be used to further the harmonisation of law and trade practices within the Community. Experience in other Regional Economic Communities has shown that this can be done in three ways: the first methods is by substitution, i.e. in so far as the Community member States have devolved power to the Community; uniform laws adopted by the Community would occupy the place and rank in the national systems of the legislation for which they are gradually substituted. The Community, through protocols, could also require amendments to national laws to meet Community requirements. Thirdly, through directives, the Community regulations could co-ordinate the process of unification. In this case it would not require legislation of the member States to make changes, but would confine itself to ordering the effects of their legislation in such a manner as to reduce any tendency to create discrimination against particular categories of persons.

57 See, F. Macini, "The Incorporation of Community Law into the Domestic Laws of Member States of the European Communities", International Law in Practice: Acts and Proceedings of the 3rd Congress on Private Law held by the International Institute for the Unification of Private Law, (Rome, 7-10 September, 1987), p. 13.

58 This is used in the EU. See K. Lipstein, Harmonization of Private International Law by the EEC, (1978). 
For uniform law to have domestic effect it must be enacted or existing legislation amended. The SADC Treaty contains provisions which can be used to further the incorporation of laws into national systems. Under Article 6, member States undertake to adopt adequate measures to promote the achievement of the objective of SADC, particularly in harmonising their strategies and policies. They are to refrain from any unilateral actions that may hinder the attainment of the objectives of the Community. In addition, each member State, in accordance with its constitutional procedures, promised to take all measures to ensure the enactment and dissemination of such legislation as may be necessary for the implementation of the provisions of the Treaty. ${ }^{59}$ They are to take measures to accord the Treaty the force of national law. ${ }^{60}$ This process would, of course, have to be achieved by means of legislative approval and official publication in accordance with the rules in each country which govern the implementation of international agreements.

It must be realised that, despite these provisions, the regulations and directives may encounter several obstacles in the individual States. Obstacles to the direct and uniform application of regulations may be created by national legislatures through delays in the adoption of the required implementing and amending measures or by the adoption of measures that conceal the Community nature of the rules concerned. Other problems derive from the conflicts which arise between Community regulations and pre-existing or subsequent ordinary domestic laws. With regard to the directives, the most delicate question concerns the possibility that they may be given direct effect and thus invoked before national courts, even in the absence of implementing legislation. The search for a solution to all these problems is a matter of the utmost importance to the proper functioning of the Community. It must be pointed out that the unification process, in order for it to be successful, requires consultation with and participation by business groups, bankers, brokers, merchants and other stake holders. This is to ensure that the rules adopted have a sound basis in the relevant business practices and customs of the Community and that the rules are sound, practical and meet the needs of those affected and those who have to operate them. In fact, such groups can provide the impetus for the harmonisation that is needed in the Community.

59 SADC Treaty, article 22.

60 SADC Treaty, article 6. 


\section{EXAMPLES OF HARMONISATION OF LAW EFFORTS BY INTERNATIONAL ORGANISATIONS}

In the efforts to elaborate texts designed to provide uniform commercial laws for SADC, several precedents can be drawn on from the work of international organisations in the field of the unification of international trade law. In some cases the adoption of a global text might, in fact, bring about the desired unification without the need to elaborate a separate regional text. There are several organisations working in this field. The leading body is the United Nations Commission on International Trade Law (UNCITRAL). UNCITRAL was established by the General Assembly in $1966 .{ }^{61}$ Its mandate is to further the progressive harmonisation and unification of the law of international trade. The Commission has elaborated several conventions and Model laws of very high standard. These include the Convention on the Limitation Period in the International Sale of Goods (New York, 1974); the United Nations Convention on Contracts for the International Sale of Goods (Vienna, 1980); the United Nations Convention on the Carriage of Goods by Sea (Hamburg, 1978); the Convention on the Liability of Operators of Transport Terminal in International Trade (Vienna, 1991); and the United Nations Convention on International Bills of Exchange and International Promissory Notes (New York). In the field of arbitration, it has developed the UNCITRAL Arbitration Rules (1976); the UNCITRAL Conciliation Rules; and the UNCITRAL Model Law on International Commercial Arbitration.

The United Nations Conference on Trade and Development (UNCTAD) has been engaged in examining the economic, commercial and development aspects of the industrial property system, patents and trade marks. In addition it has studied, on a comparative basis, the different minimum standards which are applied, at the national or international level by professional associations of shipping agents in order to consider what scope exists for the development of common guidelines for non-mandatory minimum standards for all those involved in the work of shipping agents and to prepare a draft set of standards. It also elaborated the United Nations Multimodal Transport Convention, 1980 and has been engaged in the development of model rules for multi modal container tariffs which could be used in establishing the terms and conditions of multi modal transport containers. It has further been involved in work in the field of charter

61 UNGA Res.2205 (XXI), 1966. For a description of the work of UNCITRAL, see United Nations Commission on International Trade Law, second edition, 1992. 
parties, marine insurance and maritime fraud. ${ }^{62}$ The World Intellectual Property Organisation (WIPO) and the United Nations Educational and Scientific Organisation (UNESCO) have been jointly engaged in a study designed to recommend solutions for national laws for the protection of computer programs, for works created by employee-authors. They are also engaged in studying the copyright law aspects of the rental of phono grams and video grams of direct broadcasting satellites and electronic libraries. WIPO is also engaged in drafting model provisions for legislation in the field of copyright. The Model provisions are intended to inspire and influence governments and legislators to improve their copyright laws and opt for solutions advocated therein. This will increase the degree of similarity among legislation in different States, whenever the special interests of a State do not require different solutions.

The United Nations Organisation (UNIDO) has evolved a set of legal materials including model contracts and clauses and guidelines and checklists for contractual arrangements in the following fields: capital goods; agriculture machinery, iron and steel, fertilisers, petrochemicals, pharmaceuticals, leather and leather products, vegetable oils and salts, food processing, industrial financing, training of industrial manpower, wool and wool products, building materials and build operate and transfer contracts. UNIDO has, in addition, carried out studies of investment laws in many parts of Africa and published booklets on each country. ${ }^{63}$ These booklets are designed to meet the special information needs of a potential investor, interested in investment prospects in a given African country. Each of the booklets, contains a brief account of the country, its people and resources, the basic infrastructure, the manner in which the economy has developed over the last few years, its industry, the policies and procedures for industrial licensing and transfer of know-how and the facilities which are available to anyone interested in investing in the country.

In addition , the various United Nations Regional Commissions, in their efforts to assist in raising the level of economic activity in their respective regions and to strengthen economic relations on both an intra regional and an inter regional level, have developed a number of useful texts. For instance, the Economic Commission for Africa (ECA) has undertaken studies of national legislation dealing with trade in related fields such as insurance law and investment codes whose purpose is to enable

62 UNCITRAL, Twenty-second session, "Current Activities of International Organizations", Report of the Secretary-General, A/CN. 9/324. Zimbabwe. There are investments guides on most African countries compiled by UNIDO. 
conclusions to be drawn regarding measures for the harmonisation of such legislation, especially on a sub-regional basis. In connection with the foregoing project, ECA promotes the adoption of the Brussels Tariff Nomenclature among the member States of the ECA. It reviews legislation and practices with respect to investment incentives and industrial development, and has studied the question of harmonisation of these matters among the member States. In addition, studies have been initiated on the harmonisation of legislation concerning maritime transport and on the constitutional and legal basis of public autonomous institutions and corporations. ECA has also been working in the area of harmonisation and simplification of export documents.

Other organizations working in the field of the harmonisation of law include the International Institute for the Unification of Private Law (UNIDROIT) ${ }^{64}$ The work of this Institute has formed the basis of a number of conventions in international trade and includes: uniform law on the conditions of validity of the contract of sale, credit sale and hire purchase. It has also elaborated conventions on franchising and factoring. Apart from elaborating conventions, UNIDROIT is engaged in research into ways and means of advancing the task of unification. Another organisation is The Hague Conference on Private International Law, ${ }^{65}$ which has developed a number of conventions in the attempt to unify conflicts rules in international trade law e.g. Convention on the Law Applicable to Contracts for the International Sale of Goods (1985). In addition to these world-wide organisations, a number of regional intergovernmental organisations and groupings and non-governmental organisations have elaborated texts on international trade and commercial practice which would serve as useful precedents to SADC. Unification of trade laws and commercial practice have made great progress in certain parts of the world, for instance, in the Scandinavian region. Once under way, the unification of trade laws in the SADC Community would have to be extended to other areas of common interest such as: enforcement of judgments and registration of security interests.

Since one of the purposes of unification and harmonisation of trade laws and commercial practices is to bring about changes in national laws, the difficulties of this endeavour should not be underestimated. However, the matters relating to the unification of trade laws and commercial practices

64 The Institute was founded in 1926 for the purpose of harmonising and coordinating the rules of private law of the different States, with a view to promoting gradually the adoption of a uniform system of private law.

65 The purpose of the organisation, as stated in its charter approved in 1951, is to work for the progressive unification of private international law. 
are primarily of a technical nature: it should, therefore, be less difficult to adopt regional rules on such matters than it is with respect to such matters as family law, succession, personal matters and other subjects deeply rooted in national or religious traditions. The common interest of all States to increase intra regional trade should also act as an incentive towards progress in the field. Care must be taken to ensure that unification, when it is formulated, is not at the lowest common denominator. There is no merit in harmonisation if it results in the adoption by a group of States of the legal concepts acceptable to the least progressive among them. Ways must be found, after the adoption of harmonised laws, to encourage courts to interpret unification legislation in a manner that fosters integration. One way of doing this is through seminars and a curriculum in law schools which would encourage regional thinking and foster an appreciation of regional goals. Also extremely important would be to disseminate widely within the community decisions involving the interpretation of the uniform laws adopted within the community.

The actual behaviour of the national courts is decisive in furthering harmonisation. It is in the national courts that divergent development of harmonised national laws can evolve, from the very outset, despite all endeavours at integration and harmonisation. Accordingly, if SADC integration by legal harmonisation is to be furthered, national courts would have to rethink their interpretation of the application of Community laws and Community institutions must think of ways to facilitate this. It is also important to point out that the implementation of many of the Community objectives, including that of harmonising trade law and commercial practices, will require high-level expertise in every field concerned. Availability of trained personnel and resources are of the utmost importance because when one speaks of harmonisation of trade laws and commercial practices, one is speaking about expenditure, research, implementation and high-quality elaboration of instruments to bring about the desired results.

As pointed out earlier, the Community, does not list as one of its areas of cooperation, the unification of trade laws in the Community. The danger of having no institution or structure specially charged with the task of elaborating the various legal texts for the several protocols to be done under the Treaty or with furthering co-operation in the development of the community's trade laws and commercial practices and providing for their progressive unification, means that such work would be carried out in a piecemeal manner by any one of the several sector based committees established under the Treaty for the limited purposes of that particular sector or protocol. This is unsatisfactory in view of the importance of the 
need to harmonize trade laws and commercial practices in the Community. It is suggested that an institution or structure, along the lines of the research centres for seed and that for communications, with specific responsibility for the unification of law, be established, with the following functions: the preparation of studies and recommendations on problems concerning the unification and harmonisation of the Community trade law, including comparative analysis of national legislation; studies and research on particular topics at the request of the Council of Ministers; preparation of trade conventions, model laws and uniform laws; promotion of the codification and wider acceptance of regional trade terms, customs and practices; and the promotion of ways and means of ensuring a uniform interpretation and application of regional conventions and uniform laws in the field of the law of international trade and commercial practice. It could also collect and disseminate information on national legislation and modern legal developments in the field of interuational trade law.

The proposed centre could also be concerned with the promotion of training and research in the field of integration law, in particular at SADC universities and research institutions. As has been mentioned already, the process of integration has many dimensions - political, economic, judicial, cultural, scientific, technological. All require help to determine the specific structures that could contribute to the integration process. Nevertheless, there is a tendency to associate the concept of integration only with the economic dimension and the legal and manpower implications that it carries are often ignored. Development depends to a great degree on a State's capacity for absorbing or creating technologies, and the development of its human resources. That is why research and training are so important. Research and training have a fundamental part to play in the task of achieving greater integration between states. In response to the complex problems of integration, SADC research institutes and universities must be encouraged to co-operate in the search for solutions to integration problems. They can contribute substantially in the promotion of academic activity in the integration field and generating a flow of knowledge, analysis and suggestions that would be of great value to the SADC integration process. SADC researchers can make a significant contribution to the region's integration process..

\section{J. CONCLUSION}

Southern Africa has a great opportunity to build a viable economic community and this opportunity should not be missed. Most of the major 
historical conflicts of the region have been resolved or are in the process of being resolved. Namibia attained independence in 1989; in Mozambique the conflict between FRELIMO and RENAMO has been resolved; minority rule has been ended in South Africa thereby removing the dominant source of instability in the region. Angola is implementing the Lusaka Peace Agreement. The prospects for a settlement seem good, though, the process is painfully slow. ${ }^{66}$ Except for Swaziland, democratic elections have been held in all the member States. This means that there is a commonality in political systems and outlook. This should be coupled with our earlier observation that all the countries embrace the free market system and welcome private investment.

The question that is often raised is the likelihood of any economic community in the Southern region being dominated by South Africa, the economic and pre-eminent military power in the region. This conceru needs to be addressed. It arises from the fact that South Africa's economy is far larger than the combined economies of the rest of the eleven members of SADC. Already there are complaints, especially, by Zimbabwe and Zambia that South Africa is destabilising their economies. These countries accuse South Africa of flooding the region with its goods while South Africa's tariffs prevented reciprocal trade. This may be due to the fact that South Africa has still in place a generous system of incentives for its exports put in place in the apartheid era. Zimbabwe and Zambia cannot do likewise as they are both under IMF sponsored Structural Adjustment Programmes. In 1995 South Africa's exports to the rest of the African continent jumped to $\$ 3$ billion compared with $\$ 2$ billion the previous year. At the same time, the country's imports from other African countries rose by only $19 \%$. For their imports, the other 11 members of SADC (Angola, Botswana, Lesotho, Malawi, Mauritius, Mozambique, Namibia, Swaziland, Tanzania, Zambia and Zimbabwe) depend to the extent of $70 \%$ on South Africa. In the case of Zimbabwe the country's exports to South Africa eased by $1 \%$ in 1995 while its imports from it surged by $54 \%$. Above all, the Zimbabwean textile industry, which represented $20 \%$ of its total exports at the start of the decade, is being asphyxiated by South Africa's tariffs imposed after the expiration of a bilateral trade agreement in $1992 .{ }^{67}$

There is no doubt that these difficulties can undermine regional integration and will have to be addressed. As the South African

66 A peace process is being implemented in Angola after the Angola Peace Agreement, Lusaka, 1995.

67 See, research by African Institute of South Africa, as reported by Agence France Presse, June 12, 1996. 
Government has aptly observed: "South Africa cannot be an island in an ocean of poverty. Its destiny is linked to the region." ${ }^{\prime 8}$ For one thing, South Africa will in the long run have to abide by the World Trade Organisation's trading regime. In addition, South Africa has huge domestic problems created by the legacy of apartheid which it needs to address. It needs a high economic growth rate to have sufficient resources to do this. This can only be guaranteed if the economies of the other Southern African States are vibrant. South Africa can ill afford unstable and poor neighbours with the implication such poverty has for migration from those countries to South Africa. Immigration to South Africa from the rest of Africa is already a serious problem and without cooperation by all countries in the region can only worsen. The only economic community that can work is one where all member States perceive membership as beneficial to their economies. Experience has shown, especially that of failed integration schemes, that economic integration, unless checks are put in place, tends to concentrate benefits in those countries which are relatively more developed. It is understood that all member States in an economic community cannot gain equally at any given time. In fact sometimes in the short term gains are difficult to assess and some members might lose. The long term view is the critical factor. The spirit of give and take which should be the guiding principle in regional integration has to fully prevail for a successful community to emerge. Particular measures should be instituted to take care of the less developed countries in the Community.

South Africa's economic power is a positive factor in the region. South Africa has the political and economic authority to assume a regulatory role, and the leadership capacity to consolidate and promote the cooperation process. Its expertise and advanced technology is needed and can play a vital part in the development of the region. South Africa's economic dominance places on it an obligation to act as the integration leader in the region and a responsibility to act maturely in its dealings with its partners in SADC. As Davis has observed, for integration to succeed in Southern Africa it will have to be based on five principles: (a) a regional economic programme has to be viewed as an essential component of any strategy to promote growth and development in Southern Africa; (b) inequalities in present relations need to be taken into account in developing closer regional economic ties after apartheid. If this is not done, present inequalities will be reproduced and there will not be a sustainable basis for strengthening ties, and it is likely that the socio-political consequences of such polarisation will be large-scale inigration across the sub-continent's 
borders; (c) a regional programme cannot be based on the unrealistic expectations of weaker partners. Unless all partners can expect concrete benefits, the political will to sustain a regional programme will be lacking; (d) the need to find a combination of co-operation and integration that will help to realise the benefits of closer relations; and (e) the promotion of cooperation in regional security. ${ }^{69}$

Socio-economic problems are the main threats to regional security and a new co-operative approach to security is essential to encourage disarmament and release resources for development. SADC leaders have already shown that they can act together in the crisis during the elections in Mozambique and in the resolution of the crisis in Lesotho. Water and Energy protocols have been concluded. There is also ongoing work on defence, security, police and drugs co-operation protocols. A trade protocol is also being negotiated and is expected to be concluded soon to enable its adoption to be considered at the next SADC Heads of States Summit in August $1996 .{ }^{70}$ The protocol will apparently have a ten-year framework. According to the SADC secretariat it will cover the progressive elimination of obstacles to the free movement of people, goods, capital and labour within the SADC region. As observed by the Economist Intelligence Unit, while commenting on the progress thus far made by the earlier organisation SADCC, "nearly a decade later, most of the doubters were convinced. The region's peasant farmers are beginning to plant new crop strains from a SADC research centre, while business people in different countries can telephone each other over SADC links and ship their goods through ports and railways improved under SADC auspices. Equally important, but less visible because it does not carry the SADC label, is the growing regional co-operation in a wide range of economic business, political and military matters as officials and politicians and business people get to know each other better and to think in regional terms." 71

It should also be noted that SADC was developed by its own members and a major part of the preparatory work was carried out within the region, and not presented to the member countries from outside, as was the case with many regional integration schemes, for example, COMESA, which was established in conjunction with the Economic Commission for Africa. $\mathrm{SADC}$ is an appropriate institution to serve as a vehicle for the economic

69 Minnie Venter, op. cit., supra, chapter 2, pp. 4-71, See also Laurie Nathan, $A$ Framework and Strategy for Building Peace and Security in Southern Africa, Center for Intergroup Studies, October, 1992.

70 The Xinhua News Agency, May 31, 1996.

71 Economics Intelligence Unit, SADCC in the 1990s, op. cit., supra, p. 1 
integration of Southern Africa. Integration in Southern Africa is not, however, going to be easy. Countries in the region will have to recognise that the only way to create an economic community is to harmonise economic policies and tariffs and to remove bureaucratic obstacles to the movement of capital, labour and goods within the SADC countries. These are necessary conditions for a fully integrated market and for the establishment of a free trade area. This will certainly involve the surrender of some aspects of sovereignty by individual States, but not much more than already relinquished by member States of the European Union or signatories to the North American Free Trade Association Treaty.

If Southern Africa fails to succeed to bring about economic integration, Southern African economies will stagnate and will be unable to meet the challenges facing the region. Most of the people in the region will remain poor. SADC countries must put aside narrow nationalistic tendencies in favour of co-operation, co-ordination and collaboration. Successful economic integration in Southern Africa is bound to have far reaching political, economic, social, cultural and scientific implications not only for the Southern African region but for the rest of the continent of Africa. It could serve as the much needed catalyst that finally launches Africa on the road to development. 